\title{
\begin{tabular}{|l|l}
\hline$\square$ & ФУНДАМЕНТАЛЬНЫЕ И ПРИКЛАДНЫЕ \\
ВОПРОСЫ ГОРНЫХ НАУК ТОМ 6, № 2, 2019
\end{tabular}
}

DOI: $10.15372 / F P V G N 2019060238$

\author{
ПЕРСПЕКТИВЫ ПРИМЕНЕНИЯ ЦЕОЛИТСОДЕРЖАЩИХ ПОРОД \\ ВОСТОЧНОГО ЗАБАЙКАЛЬЯ ДЛЯ КОМПЛЕКСНОГО ОБЕСПЕЧЕНИЯ \\ ЭКОЛОГИЧЕСКОЙ БЕЗОПАСНОСТИ ГОРНОДОБЫВАЮЩИХ ПРЕДПРИЯТИЙ
}

\author{
К. К. Размахнин
}

\begin{abstract}
Институт горного дела им. Н. А. Чинакала СО РАН (Читинский филиал), E-mail: constantin-const@mail.ru, ул. Александро-Заводская 30, г. Чита 672039, Россия
\end{abstract}

\begin{abstract}
Дана оценка ресурсному потенциалу цеолитсодержащих пород Восточного Забайкалья, рассмотрены геоэкологические аспекты их добычи и комплексной переработки. Определена доля влияния климата на устойчивость природных комплексов при негативном воздействии цеолитового производства. Предложены основные направления по снижению техногенной нагрузки на окружающую среду.
\end{abstract}

Цеолитсодержащие породы, обеспечение экологической безопасности, комплексное использование, обогащение и переработка

\section{PROSPECTS OF THE USE OF ZEOLITE-BEARING ROCKS FROM EASTERN TRANSBAIKALIA TO PROVIDE FOR THE INTEGRATED ENVIRONMENTAL SAFETY OF MINING COMPANIES}

\author{
K. K. Razmakhnin \\ Chinakal Institute of Mining, Siberian Branch, Russian Academy of Science (Chita branch), \\ E-mail: constantin-const@mail.ru, ul. Alexandro-Zavodskaya 30, Chita 672039, Russia
}

\begin{abstract}
The resource potential of zeolite-bearing rocks in Eastern Transbaikalia is evaluated. The prospects of complex development of zeolite-bearing rocks and their processing in the Transbaikal territory are studied. The climate-related factors affecting stability of natural complexes under anthropogenic impact are determined. The main directions for reducing the negative impact of zeolite production on the environment are defined.
\end{abstract}

Zeolite-bearing rocks, providing for environmental safety, integrated use, beneficiation and processing

Россия обладает значительными запасами природных цеолитов (более 70 месторождений и рудопроявлений). Суммарные запасы и прогнозные ресурсы цеолитовых пород составляют около 25 млрд т со средним содержанием в них цеолитов 25-35\% [1]. Наиболее крупные месторождения цеолитов находятся в Красноярском крае (Пашенское, Сахаптинское, Вознесенское), в Иркутской области (Бадарминское), Кемеровской (Пегасское), в Забайкальском крае и в Бурятии (Шивыртуйское, Холинское, Бадинское, Талан-Гозагорское), в Приморском крае (Середочное, Чугуевское), на Сахалине (Лютогское, Чеховское), в Республике Якутия (Хонгуруу, Сорос, Чучуба) [1].

Забайкальский край обладает наибольшими потенциальными возможностями для создания крупной сырьевой базы цеолитсодержащего сырья. В настоящее время можно говорить о наличии в этом регионе четырех крупных и двадцати средних объектах цеолитсодержащего сырья. Все они находятся в благоприятных географических условиях вблизи транспортных путей и экономически освоенных районов. Наибольший промышленный интерес представляют Шивыртуйское, Холинское, Бадинское и Талан-Гозагорское месторождения, суммарные запасы которых оцениваются приблизительно в 17 млрд т [2]. 
Месторождения природных цеолитов Забайкалья представлены в большей степени клиноптилолитом, морденитом и шабазитом, которые, исходя из своих свойств, могут широко применяться в различных отраслях. В настоящее время в Забайкальском крае разрабатывается только Холинское месторождение, цеолитсодержащие породы которого имеют достаточно высокую востребованность в медицине, сельском хозяйстве и сорбционных технологиях. Шивыртуйское месторождение находится в законсервированном состоянии, хотя в недавнем прошлом продукция, изготовленная из шивыртуйских цеолитов, пользовалась высоким спросом у потребителя. Бадинское месторождение не разрабатывается по причине канцерогенности входящего в состав пород большого количества морденита. Талан-Гозагорское месторождение (проявление) представлено наиболее ценным видом цеолита - шабазитом, однако до промышленной разработки данного объекта дело так не дошло.

Большие надежды по развитию сырьевой базы цеолитов в Приаргунском районе Забайкальского края связаны в первую очередь с решением Правительственной комиссии при участии Фонда развития моногородов по удовлетворению заявки города Краснокаменска на статус территории опережающего социально-экономического развития (ТОСЭР). В ближайшее время, в соответствии с разрабатываемой программой “Цеолиты Забайкалья”, предполагается внести заявку по разработке Шивыртуйского и Талан-Гозагорского цеолитсодержащих месторождений в план развития моногорода, поддержка которой обеспечит регион качественным сырьем для производства целой линейки продукции, находящей применение в медицине, экологических и строительных технологиях, сельском хозяйстве и пр. На основе уже имеющегося производственного комплекса по переработке цеолитсодержащих пород (в настоящее время законсервирован) в г. Краснокаменск возможно создание полноценного комбината по переработке, обогащению и получению товарной продукции из цеолитов Шивыртуйского и Талан-Гозагорского месторождений.

Добыча и переработка цеолитсодержащих пород в районе г. Краснокаменск будет способствовать не только развитию промышленности, инфраструктуры и социальной сферы, но и окажет дополнительную нагрузку на экологию прилегающей территории. При этом будут иметь место геоэкологические последствия, к которым можно отнести нарушение функционирования экосистем, загрязнение атмосферы, почв, поверхностных и подземных вод, нарушение ландшафта. Одними из основных отрицательных результатов деятельности промышленного предприятия, оказывающих наибольшее воздействие на природные комплексы и экосистемы территории, являются масштабные нарушения окружающей природной среды, которые выражаются в отчуждении, частичном или полном уничтожении (вырубка, повреждение почвенного покрова и т. д.), нарушении условий существования фауны [3].

Известно, что доля негативного воздействия горных предприятий ограничивается площадью непосредственного влияния, которое при проведении эффективных природоохранных мероприятий может быть минимизировано. Однако интенсивное воздействие промышленной зоны на прилегающую территорию требует внедрения не только природоохранных мероприятий, но и ресурсосберегающих технологий во всех циклах производства от добычи минерального сырья до получения готовой товарной продукции. Комплексное использование цеолитсодержащих пород предполагает применение направленных энергетических и физико-механических методов воздействия, зачастую химических методов переработки, например, для получения алюмосодержащих продуктов кислотным или щелочным способом, которые могут оказывать достаточно серьезное негативное воздействие на окружающую среду.

Важным вопросом является комплексность использования отходов, образуемых при переработке цеолитсодержащих пород. В настоящее время с учетом географии, промышленного и инфраструктурного развития региона отходы цеолитового производства могут быть применены 
в строительных технологиях, при закладке выработанного пространства (шахт, карьеров), при отсыпке автодорог и пр. Такой системный подход к комплексному использованию минерального сырья позволит практически полностью отказаться от складирования отходов на специальных площадках и тем самым снизит нагрузку на основные компоненты окружающей среды, что крайне важно в свете и без того высокого антропогенного воздействия на данный регион. Кроме того, упраздняя комплексным подходом к переработке цеолитсодержащих пород отвалы и хвостохранилища, которые нарушают экологическую обстановку региона, исчезает потребность и в принятии мер и затрат для их захоронения или защиты от выветривания, окисления и т. п. Анализ современного состояния вопроса комплексного использования минерального сырья показывает, что производственные процессы по его добыче и переработке, а также получение из него товарных продуктов должны быть замкнуты в единый технологический цикл, что возможно только при условии, когда отходы одного производства становятся сырьем для другого. Таким образом, при построении технологических схем переработки цеолитсодержащих пород необходимо руководствоваться концепцией безотходного производства, предполагающей переход от процессов концентрирования к разделению цеолитсодержащего сырья на составляющие их структурные элементы. Такой подход должен осуществляться на всех стадиях отработки месторождений цеолитсодержащих пород с селективным выделением технологических типов и сортов пород, каждый из которых находит практическое применение. При этом некоторые типы и сорта цеолитовых пород могут быть использованы без предварительного обогащения (если содержание цеолитов в них достигает 95-98\%). Однако большая часть пород рассматриваемых месторождений представлена небогатым по содержанию ценного компонента (цеолита) сырьем, что требует разработки технологий его концентрации и очистки от вмещающих примесей. Такие технологии должны обеспечивать эффективное обогащение цеолитсодержащих пород, быть ресурсосберегающими, а также гарантировать минимальный ущерб окружающей природной среде.

Широкое применение цеолитов сдерживается, как правило, низким качеством исходного сырья, поэтому цеолитсодержащие породы, как и традиционное минеральное сырье, должны подвергаться обогащению. В качестве основных методов обогащения возможно использование гравитации, магнитной и электрической сепарации, направленной физико-химической модификации и активации свойств цеолитсодержащих пород.

Принимая во внимание известные и разработанные авторами закономерности при обогащении цеолитсодержащих пород можно выделить два цикла с соответствующими операциями, определяющие принципы построения технологических схем их переработки - подготовительный, включающий при необходимости некоторые специальные физико-химические операции, и основной цикл. К операциям подготовительного цикла относятся дробление, измельчение, предварительная обработка ультразвуком, сушка, механические и механохимические методы воздействия, гидрохимические воздействия, энергетические воздействия, грохочение и обеспыливание.

После подготовительного цикла применяется основной, где из цеолитсодержащего сырья практически полностью удаляются железосодержащие примеси, минералы кварца и полевые шпаты. Этот цикл осуществляется магнитной и электростатической сепарациями. Электростатическая сепарация является достаточно эффективным методом удаления из цеолитсодержащего сырья минералов кварца, слюд и полевого шпата, а использование салициловой или бензойной кислот для контрастного заряжения поверхности минералов в течение 30-60 мин обеспечивает наиболее полное отделение указанных примесей из материала крупностью $-0.074+0.5$ мм.

К числу специальных физико-химических операций, вводимых в технологическую схему переработки цеолитсодержащих пород, относится обработка материала парами салициловой или бензойной кислоты для интенсификации процесса электростатической сепарации, также могут быть применены гидрохимические методы воздействия и мощные электромагнитные 
импульсные воздействия. Использование указанных специальных физико-химических операций является обязательным только при необходимости направленного физико-химического модифицирования свойств цеолитов в соответствии с требованиями отраслей народного хозяйства.

Подготовительный цикл при переработке цеолитсодержащих пород должен включать механическую или механохимическую обработку. Одна из наиболее эффективных операций подготовительного цикла при обогащении цеолитсодержащего сырья - его предварительная ультразвуковая обработка, которая приводит к интенсификации процесса отделения цеолита от минералов примесей (полевого шпата, монтмориллонита, кварца, плагиоклаза и др.), что обеспечивает наибольшую продуктивность применения магнитной и электростатической сепарации. Использование энергии ультразвукового поля усиливает диспергирующий эффект вследствие точечной эрозии твердой поверхности на границе фаз и ускоряет процесс концентрирования цеолитов. Отметим, что при ультразвуковой обработке цеолитсодержащего сырья достигается довольно высокая степень отделения глинистого компонента. Установлено, что обработку цеолитсодержащего сырья ультразвуком следует проводить при частоте 22 кГц. При этом сокращается количество перечистных операций в технологической схеме и повышается содержание цеолита в концентрате до 85-95\%. Анализ ИК-спектров цеолитсодержащих пород свидетельствует о повышении содержания цеолита в обработанных ультразвуком пробах. Определенные на основе отечественного и зарубежного опыта выделения цеолитов направления применения сепарационных методов представлены в таблице.

Основные методы сепарации цеолитов в зависимости от минерального состава породы

\begin{tabular}{|c|c|c|}
\hline $\begin{array}{c}\text { Выделяемый } \\
\text { минерал }\end{array}$ & $\begin{array}{c}\text { Преобладающие } \\
\text { минералы-спутники }\end{array}$ & Способ концентрирования \\
\hline \multirow{7}{*}{$\begin{array}{l}\text { Цеолит, } \\
\text { шабазит }\end{array}$} & \multirow{4}{*}{$\begin{array}{l}\text { Полевые шпаты, } \\
\text { Слюды > } 50 \text { мкм }\end{array}$} & $\begin{array}{l}\text { Дробление в роторных дробилках и измельчение в } \\
\text { шаровых мельницах } \\
\text { Механохимические воздействия }\end{array}$ \\
\hline & & $\begin{array}{l}\text { Ультразвуковая обработка } \\
\text { Гидрохимические воздействия } \\
\text { Направленные воздействия }\end{array}$ \\
\hline & & $\begin{array}{l}\text { Магнитная сепарация на сепараторе с системой } \\
\text { из постоянных магнитов или на электромагнитном } \\
\text { сепараторе с изодинамическим полем }\end{array}$ \\
\hline & & Электростатическая сепарация \\
\hline & \multirow{3}{*}{$\begin{array}{l}\text { Глинистые } \\
\text { минералы < } 50 \text { мкм }\end{array}$} & Ультразвуковая обработка \\
\hline & & Магнитная сепарация \\
\hline & & $\begin{array}{l}\text { Электростатическая сепарация с подогрев- } \\
\text { электризацией }\end{array}$ \\
\hline \multirow{3}{*}{$\begin{array}{l}\text { Цеолит, } \\
\text { шабазит }\end{array}$} & \multirow{3}{*}{$\begin{array}{l}\text { Минералы группы } \\
\text { кварца, глинистые } \\
\text { минералы }\end{array}$} & $\begin{array}{l}\text { Дробление в роторных дробилках и измельчение } \\
\text { в шаровых мельницах } \\
\text { Механохимические воздействия }\end{array}$ \\
\hline & & $\begin{array}{l}\text { Ультразвуковая обработка } \\
\text { Гидрохимические воздействия } \\
\text { Направленные воздействия }\end{array}$ \\
\hline & & Электростатическая сепарация \\
\hline
\end{tabular}

Если сопутствующие минералы образования представлены в основном минералами группы полевых шпатов и слюд, а другие минеральные разновидности имеют подчиненное значение, то целесообразно применять электромагнитную сепарацию, электростатическое обогащение. 
В случаях, когда в минеральных комплексах размеры цеолитов условно менее 50 мкм, то электростатическую сепарацию следует проводить с помощью подогрев-электризации парами салициловой или бензойной кислоты, а удаление железосодержащих примесей - электромагнитной сепарацией. Использование в комбинированной схеме переработки электромагнитных и электростатических методов позволяет существенно снизить количество сопутствующих минералов и довести содержание цеолитов до $80-90 \%$.

Выбор и компоновку технологических схем переработки цеолитсодержащих пород необходимо осуществлять прежде всего с учетом фракционного состава сырья и его физико-химических свойств, характеризующих взаимосвязь между разделительными признаками вмещающих минералов и содержанием ценного компонента в исходном сырье. Отметим, что методологические основы разработки и выбора технологических схем переработки цеолитсодержащих пород и компоновки оборудования для их реализации базируются на критериях оптимальности - техники безопасности, максимального извлечения ценного компонента из недр и рационального использования природных ресурсов. Основные принципы, реализуемые во вновь создаваемых технологических схемах модификации цеолитсодержащего сырья, определяются введением следующих переделов: механохимические (механодеформационные) методы воздействия, ультразвуковая обработка перед грохочением материала, глубокая очистка от железосодержащих примесей, электростатическая сепарация для удаления немагнитных примесей, направленные виды воздействия, гидрохимические методы воздействия.

Территория расположения Шивыртуйского и Талан-Гозагорского месторождений цеолитов является крупным промышленным узлом. При этом обеспечение условий экологического равновесия требует проведения глубокого системного анализа последствий хозяйственной деятельности промышленных объектов цеолитового производства на окружающую природную среду, прогноз ее изменения и разработку системы необходимых природоохранных мероприятий в соответствии с особенностями техногенного воздействия и реакцией природы. При разработке системы природоохранных мероприятий необходимо уделить особое внимание региональным критериям, учитывающим слабую устойчивость природных комплексов к антропогенным воздействиям, и не допустить формирования неустойчивой экологической системы с нарушенными структурными и функциональными параметрами.

Необходимо отметить, что слабая устойчивость природных комплексов определена отчасти достаточно суровыми климатическими условиями Приаргунского района. Климат данного района резко континентальный, среднегодовая температура воздуха $-2.2^{\circ} \mathrm{C}$, среднегодовая скорость ветра составляет $1.3 \mathrm{~m} / \mathrm{c}$, лето засушливое, зимы малоснежные и морозные. Рельеф местности в планируемом районе расположения производства приближен к равнинному, что обеспечивает достаточно эффективное рассеивание промышленных выбросов, и отсутствие их повышенной концентрации в приземном слое в районе крупных населенных пунктов. Все эти факторы, включая резко континентальный климат, длительный холодный период, глубокое сезонное промерзание почв и грунтов, определили формирование в Приаргунском районе малоустойчивых природных систем, которые могут быть нарушены под воздействием человеческой деятельности, заметно ухудшив при этом состояние и качество природных комплексов.

\section{ВЫводы}

Оценка геоэкологических аспектов добычи и переработки цеолитсодержащих пород Восточного Забайкалья показала необходимость применения системного подхода к вопросам развития цеолитовой промышленности в данном регионе, который должен учитывать комплексность использования минерального сырья, экологичность применяемых технологий и ресурсосбережение при общей минимизации техногенной нагрузки на окружающую природную среду. 


\section{СПИСОК ЛИТЕРАТУРЫ / REFERENCES}

1. Yusupov T. S. Methods of concentration and separation of zeolites from rocks, Methods of diagnosis and quantitative determination of zeolites in rocks, Novosibirsk, IGG SB AS USSR, 1985, pp. 161-168 [Юсупов Т. С. Способы концентрирования и выделения цеолитов из горных пород // Методы диагностики и количественного определения содержания цеолитов в горных породах. - Новосибирск: ИГиГ СО АН СССР, 1985. - С. 161 - 168.]

2. Pavlenko Y. V. Zeolite deposits of Eastern Transbaikalia. Chita, Chita SU, 2000, 101 pp. [Павленко Ю. В. Цеолитовые месторождения Восточного Забайкалья. —Чита, ЧитГУ, 2000. — 101 с.]

3. Faleichik L. M. Geoinformation models in the assessment of damage to natural systems as a result of economic activity, Vestnik of TSU, 2014, no. 08 (111) [Фалейчик Л. М. Геоинформационные модели в оценке ущерба природными системами в результате хозяйственной деятельности // Вестник ЗабГУ. — 2014. — № 08 (111).] 